Article

\title{
Toward an Ecological Monetary Theory
}

\author{
Joe Ament 1,2 \\ 1 Gund Institute for Environment, University of Vermont, Burlington, VT 05405, USA; jament@uvm.edu \\ 2 Rubenstein School of Environment and Natural Resources, University of Vermont, Burlington, \\ VT 05405, USA
}

Received: 31 December 2018; Accepted: 2 February 2019; Published: 12 February 2019

check for updates

\begin{abstract}
Money is the most ubiquitous institution on the planet and lays the foundation for human civilization. As such it should underlie economic theory. Due to the dualized nature of Western culture, however, mainstream economic theory assumes that money is simply a value relation to make barter efficient. This theory is manifest in orthodox monetary theory and policy. Ecological economics understands the problems attendant to modern money but has heretofore not developed a theory of money of its own. In order to make its economic theory and policy prescriptions viable, this paper argues that ecological economics must develop a theory of money that is simultaneously rooted in an understanding of money's socio-history, and an ontological reimagining of dualized Western culture.
\end{abstract}

Keywords: monetary theory; ecological economics; ecofeminism; dualism; monetary policy; state theory; credit theory

\section{Introduction}

Western society and culture are characterized by hierarchical dualisms in which reality is divided into superior/inferior pairs [1,2]. This manifests itself in mainstream economic theory as an atomistic, mechanistic model that denies input dependency on the one hand and focuses on geometric equilibrium on the other [3] (p. 277). In order for this atomistic model to function, money must be treated as a neutral commodity that facilitates barter exchange ([4], p. 49; [5], p. 277). Accordingly, any socio-historical dynamics or spatiotemporal asymmetries must be denied. The policy attendant to the orthodox understanding of money acquiesces control of the money supply to commercial banks [6] who are assumed to act as neutral arbiters of barter-based money. Such a profit-driven money supply engenders ecological and social consequences as wealth is transferred from borrowers to rentiers [7] and resources are extracted to support the money supply.

Ecological economics provides an alternative to mainstream economic theory by acknowledging that economic processes are energetic processes that are subject to entropy [8]. Frederick Soddy, one of the field's intellectual progenitors [9] (p. 297), drew a distinction between entropic physical wealth and money as a non-entropic virtual representation of that wealth [10]. Daly, influenced by Soddy, has argued that without fundamental changes in our approach to money, the ecological economic alternative "may prove insufficient" [11] (p. 407). Yet, as of this writing, ecological economics has not developed a theory of money.

Stepping outside of the mainstream, heterodox, and ecological economic spheres reveals a broad monetary literature that argues that barter-based economies have never existed [12] and, far from being neutral, money is the most social institution on the planet [13] and [14] (p. 202). Combining money's socio-historical importance with the dualism implicit in Western culture, this paper's central argument is, thus, three-fold. First, since the barter assumption is historically false: the ecological economics critique is most effective when levied at this central failing of the mainstream model. Second, since 
money as an institution is a foundation of human civilization, it must play a central role in economic theory. Third, a theory of money should be rooted in an explicit rejection of dualism.

Economics is the weakest foundation of the ecological economics transdiscipline due in part to its absent theory of money. A sound theory of the economy embedded in society embedded in the biophysical must rest on a sound theory of money [15] (p. 5). It is inefficacious, however, to attempt to understand the impacts of money without first understanding the atomism at the center of orthodox economic and monetary theories. Accordingly, in order to provide a viable alternative to mainstream economics, ecological economics must develop a foundational theory of money that is simultaneously rooted in a social understanding of money and an ontological re-imagining of the relationship amongst and between humans and nature. Without such a theory of money, ecological economics risks importing flawed monetary theories and dualistic social/ecological ontologies, and accordingly, proposing inefficacious and contradictory policies. Botanist Edred Corner wrote that "the value of theory is proved by what cannot be done without it" [16]. An ecological monetary theory is valuable for its ability to provide the economic foundation that has heretofore been missing and upon which ecological economics' theories and policies may efficaciously rest.

\section{Western Ontology as a Mechanical Dualism}

Ecofeminism provides a useful framework from which ecological economics can address the "ecological destructiveness of the Western socioeconomic system" [17] (p. 16). As a trasndiscipline, ecofeminism understands gender, race, class, and natural oppression as rooted in the dualistic structure of Western thought and culture [2] (p. 248) [17,18].

Dualisms organize reality into hierarchically ordered pairs [1] (p. 129) [18] (p. 47) and are constructed around oppressive conceptual frameworks that justify the subordination of the inferior [19] (p. 128), distinguishing dualism from dichotomy [18] (p. 47). Accordingly, women, nature, the body, and marginalized groups are constructed as inferior and subordinate to men, culture, the mind, and powerful groups, respectively. As Plumwood argues, dualism embeds hierarchy by denying the superior's dependency on the inferior, objectifying the inferior in terms of its usefulness to the superior, and homogenizing the inferior group [18] (pp. 48-54).

Hierarchical dualism generally emerges with the philosophy of Plato and Aristotle in early Greece [1] (p. 129). Plato associated the feminine with the lower sphere of nature that is formless and chaotic [20] (p. 50) and treated the body as a prison from which the masculine soul can escape by attaining wisdom [21] (p. 200). Aristotle ordered form in a superior relation to matter within each body [3] (p. 13) by treating matter as the "passive recipient of form" [11] (p. 191). This works to create a divided self in which the rational mind struggles against the appetitive body and frames the notion of "purpose and function" [22] (p. 246) where inferior realms function in service to the superior's purpose [22] (p. 247).

While a servile hierarchy was explicit in the Greek frameworks, the relationship was ultimately rooted in an organic theory that viewed nature as a living being [23] (p. 452) that was the source of movement in an interdependent universe [3] (p. 11). As feudalism unraveled into mercantilism and the relationship with religious authority began to shift, however, the idea that order was maintained through an organic hierarchy [3] (p. 193) was disrupted by way of atomistic social and political shifts [24] (p. 37). Order thus became the fundamental social and intellectual problem as philosophers, scientists, and mathematicians sought to develop a "framework based on the [...] origin and transmission of motion" [3] (p. 207). Technological and mathematical innovations offered the machine as a metaphor for understanding the motion of individual entities moved by predictable and controllable external forces.

Rene Descartes drew upon hierarchical dualism to lay the foundation for a mechanistic worldview [25] (p. 278) by accepting ideas associated with order and control, and rejecting those associated with change and uncertainty. This was done by drawing a distinction between internal and external nature and transitioning Aristotle's organic soul/nature dualism into a mechanistic 
mind/nature dualism that denied inferior entities any features of the rational mind [18] (p. 104). Mathematics was viewed as an objective system of natural laws and thus any subjectivity or interrelation was systematically eliminated [26] (p. 175). Accordingly, for Descartes, nature, animals, and females operated by means of dead, atomistic matter that moved by external efficient causes without intentionality of their own [18] (p. 125). This structured reality along the lines of consciousness versus clockwork [27] (p. 113) and allowed disorder to be understood and controlled through mathematical objectivity [23] (p. 452).

Karen Warren argues that dualism and mechanism are not problematic themselves, but are problematic in "the way in which [they are] used [ ... ] to justify subordination" [19] (p. 128). As new technology was coalescing with new social and economic structures in the seventeenth century, the machine metaphor provided that justification and removed any scruples associated with extraction for economic gain [3] (p. 277) [28]. This transition from the Platonic goal of attaining reason, to the Cartesian emphasis on conquest and control marks a unique turning point in Western civilization. It also reflects a changing social contract.

While Descartes was primarily concerned with natural disorder, Hobbes applied the mechanical model to social disorder. Hobbes viewed society as a machine consisting of atomistic beings united through "competition and self-interest" and governed from outside by a technician-like sovereign [3] (p. 210). Newton added to this mechanical social philosophy a mechanical physics rooted in mathematics [ibid] (p. 276). This theory embodied a strict dualism between passive, atomistic bodies that are moved by external forces [ibid] and replaced concepts of value, purpose, or spatial hierarchy with geometric stability and structure [ibid] (p. 277).

Growing from Hobbes' atomistic social theory and Newton's mechanics, Jeremy Bentham developed the philosophy of utilitarianism in which the best individual action is the one that increases pleasure and reduces pain. Since for Bentham, drawing from Hobbes, the community was the sum of its individuals [29] (p. 40), the best community action is the one that increases the net pleasure of the community, regardless of individual pain. The hierarchical dualism implicit in pleasure-seeking and pain-avoidance works, in the case of the emerging commercial capitalism [3] (p. 16), to objectify resources and labor in terms of their usefulness in delivering pleasure to the superior [17] (p. 16) [18] (p. 52).

\section{Economic Theory}

\subsection{Classical Economics}

Adam Smith's The Wealth of Nations reflects the mechanistic individualism that began to take root in the seventeenth and eighteenth centuries. His iconic description of a self-interested invisible hand is Benthamian in its utilitarianism and Hobbesian in its atomistic deference to a technician who controls society from above. While Smith was an "historical and humanistic" [11] (p. 28) economist, by reducing an economy to its individual parts he established the discipline of economics as a science in the Newtonian tradition [30] (p. 44) and paved the way for the economics that would follow.

Smith's work rests upon Locke's contemporarily novel argument [31] that mixing one's labor with "whatsoever he removes" [32] from nature constitutes ownership. This atomistic idea, however, fails to incorporate how removing resources from nature affects the utility of more than just the laborer [33]. Locke's utilitarian proviso that resource ownership was legitimate so long as man left "enough and as good" [ibid] for others was explicitly dualistic, arguing that "the earth and all inferior creatures [are] common to all men" [32]. As Plumwood points out, Locke's argument assumes that pristine nature is "unowned by other humans" and is a "nullity" until imbued with value by human (male) labor [18] (p. 111).

Mill's economic theory built upon Bentham and Hobbes to argue that the role of the state is external to the freedom of individuals to pursue utility "so long as that action does not harm other persons" [33]. As Maria Mies argues, however, freedom itself is necessarily a dualism because the 
"autonomy of the subject is based on the heteronomy of some Other" be it nature, other humans, or the subordinated parts of the self [34] (p. 223).

\subsection{Neolassical Economics}

During the 1870s economists began to apply Newtonian mechanical mathematics [35] (p. 45) to the classical theories of political economy [36] (p. 102). Since "mathematics can only work with what can be formalized" [11] (p. 31), however, mechanical economics subordinated nature and the corporeal body to create an economics focused on "the mechanics of utility and self-interest" [37] (p. 21). Drawing from Bentham and Mill, Pareto defined economic efficiency as a socially optimal allocation of resources in which it is impossible to increase one person's utility without diminishing another's [38] (p. 247). Since interpersonal comparisons of utility are impossible, however, price became a proxy for utility preferences [ibid] (p. 248).

Léon Walras formalized Pareto's economic theory in a mathematical model of a pure barter economy. In the Walrasian model, atomistic economic actors exchange market commodities according to endogenous utility preferences and budget constraints until Pareto efficiency is achieved. If prices perfectly capture all relevant information about the utility and profitability of commodities and inputs, respectively, perfectly competitive markets will exactly duplicate the Pareto efficiency of a pure barter system [39] (p. 209) [40] (p. 2). Accordingly, social welfare, as defined by utility and profit, is maximized in competitive markets where the downward sloping demand curve of consumers is in equilibrium with the upward sloping supply curve of producers.

John Hicks applied the Walrasian model to Keynes' General Theory [41] to create a neoclassical macroeconoimc equilibrium model [13] (p. 509) [42] (p. 154). In this model, the relationship between interest and income that makes savings equal investment (IS) and fluctuates the demand for money (LM) maximizes social welfare where IS and LM equilibrate in price/quantity (interest/income) space. In disaggregating the money market from the productive market, the IS-LM macroeconomic model adopts the atomism and price rationality of the Walrasian microeconomic model.

\subsection{Orthodox Economics as Dualistic Ontology}

While modern economists have added criterion to the Walrasian microeconomic and the IS-LM macroeconomic models, their fundamentals continue to dominate academic and policy spheres [43] (p. 489) [44]. As Gowdy writes, "this system has held sway for so long [because] it is [ ... ] a logically consistent representation of Adam Smith's Invisible Hand" [40] (p. 69). In order to mechanize Smith's and Hobbes' observations about self-interest and social equilibrium, however, strict assumptions about, and abstractions from, reality were required. Those assumptions rest upon (1) a Cartesian dualization in which all that is not human and masculine is backgrounded in service to that which is, and (2) a Newtonian atomistic mechanics in which complexity and interdependence is superseded by equilibrium-seeking geometrical structures.

The entire system, micro and macro, hinges upon the price mechanism equilibrating supply and demand. Since price-revealed utility preferences are the only preferences of import, however, and since utility is only generated through consuming and producing commodities, price comes to dominate social and ecological systems [45] (p. 92). By constructing price this way, the neoclassical model creates a dualization "between different spheres of human behavior" [30] (p. 33) and atomizes the interdependence of social and ecological systems.

This dualization fails to account for labor and natural resources, outside of their respective market prices, in the derivation of supply and demand. The model homogenizes the circular, wage, and slave labor embedded in commodities and productive inputs [46] and [47] (pp. 46-55) and disembodies labor from its biological function [1] (p. 130). From a resource perspective, commodities are viewed in terms of a "mechanistic ontology" [48] (p. 11) with no inherent value until labor or capital actualize their value in the form of producer profit or consumer utility [11] (p. 192) [18] (p. 111). 
The assumption that all individuals and firms are "atomistic agents" [40] (p. 48) whose utility functions are independent of one another and independent of the commodity's own utility [49] (p. 14), denies social [50] (p. 953) and ecological [33] interdependence. Similarly, the asocial and finite exchanges between the model's barter actors obscures the embodied social relation implicit within exchange [51] (p. 36). Yet, these unrealistic and atomistic assumptions are necessary in order to achieve mathematical equilibrium [40] (p. 18) and model economic science after the Newtonian paradigm of mechanical dynamics [52] (p. 17).

\section{Money}

\subsection{Money in Orthodox Theory}

\subsubsection{Price Numeraire as Value Relation}

In the Walrasian model, price acts the single tool through which all information about commodities is revealed while also serving as the single feedback loop that equilibrates supply and demand. Price, however, is not money per se, but a measure of the relative utility between two "existing commodity values" [14] (p. 18) and a third commodity of invariable value that Walras called the numeraire [53] (p. 215).

An "omnipotent auctioneer capable of knowing all exchange and utility values at all times" [54] (pp. 31-32) sets the numeraire price to one and it becomes the price relative to which all other prices are interpreted [55] (pp. 26, 613). But price is not money. It is the relative utility value of commodities that establishes market equilibrium and allows the first fundamental theorem to state that if prices perfectly reflect utility, a competitive market is the same as barter.

\subsubsection{Classical Materialism, Neoclassical Neutrality, and Medium of Exchange}

For the classical economists, value was inherent in land, labor, and the production process [54] (p. 30). Aristotle and Smith both argue that money is an outcropping of the process of individuals bartering in value. For Aristotle, barter temporally merges purchases and sales into one transaction [56] (pp. 26-27). For Smith, specialization causes merchants to spatially lack what they need while holding an excess of what they create [57] (p. 21). The temporal and spatial inconveniences of barter leads to the classic "double coincidence of wants" problem wherein, during a transaction, both individuals must simultaneously have the good the other wants and want to good the other has [58] (p. 32).

To avoid this problem, the story goes, people began to hold certain commodities that "few people would be likely to refuse in exchange for the produce of their industry" [57] (p. 21). Precious metal, in this view, being both universally acceptable and divisible, naturally emerged as money, and was "singled out as the commodity through which all barter must occur" [29] (p. 360).

In other words, money is a medium of exchange that represents underlying commodity values, though without any value itself, and allows economic agents to store value in time and space-to lubricate the gears of trade [13] (p. 508). This explains why Walras' price represented relative value, not money. It also explains Mill's argument that "money [ ... ] does not interfere with the operation of any laws of value" [59] (p. 341), and Say's contention that "products are paid for by products" [60] (p. 178), "and when the transaction is [ ... ] closed [ ... ] one [ ... ] commodity has been exchanged for another"[ibid] (p. 138).

Contemporary mainstream economics views money the same way as Walras, Smith, Mill, and Say. Samuelson wrote that "money is a neutral veil that obscures barter transactions just below the surface" [4] and argues, were it not for the inconvenience of barter, "money [ ... ] might have little function" [61] (p. 481). Schumpeter echoes Mill in writing that money is a "technical device that has been adopted in order to facilitate transactions [ ... ] [between] [ ... ] goods and services" [5] (p. 277). Wheelan writes that "in theory money is not even necessary" [62]. 
Economic theory almost ubiquitously defines money according to its three functions: a medium of exchange, a store of value, and a unit of account. Given the barter-commodity theory of money's origins, however, medium of exchange is treated as the "key function" from which all others follow [14] (p. 24). The notion that money is engendered primarily as a medium of exchange that arbitrates the price-value relation between commodities gives rise to the concept of monetary neutrality that Schumpeter explains as the idea that money "does not affect the economic process, which behaves in the same way [with money] as it would in a barter economy" [5] (p. 277). The Arrow-Debreu General Equilibrium model formalized this theory by showing that markets will gravitate toward an equilibrium price without the existence of money. Since the model can reach equilibrium without the existence of money, it was used as proof that "money was extraneous to worthwhile economic analysis" [63] (p. 214) and is effectively rendered redundant by the price relation [14] (p. 18). It is here that the commodity theory, the barter origin, the medium of exchange primacy, and the price-value relativity come together to inform modern economic theory and its attendant policy prescriptions, most importantly, modern money creation.

\subsubsection{Neoclassical View of Money Creation}

John Locke was a scientific materialist who, much like Hobbes, saw human behavior as founded in natural laws from above. For him, money's durability and force for economic growth circumvented the two limits of his theory of private property, i.e., spoilage and sufficiency, respectively [64]. In his tenure as Warden of the British Mint, Locke advised Newton to recall and reissue coins of deflating value because the social value imbued in the coin was less important than the State-verified weight of the coins silver for which merchants, in his view, actually contracted [30] (p. 340).

This idea that the role of the state is to maintain measures in order that commodity money may be allocated amongst market actors informs the orthodox view of money and banking. According to orthodoxy, money grew out of barter and banking grew out of money [30] (p. 40) [65] (pp. 80-85), each of the latter responding to the temporal and spatial incongruences of the former. It follows that banks function as intermediaries between savers (lenders) and investors (borrowers), as made explicit in the equilibrium-seeking IS-LM model. Krugman and Mankiw both argue that banks lend to investors what savers have "stashed" with the bank after cutting back on spending [66,67] and [68] (p. 260).

Since money cannot exist at the same time as both a saver's deposit and a borrower's loan, banks must create money when they extend saver's money as credit to borrowers [69] (p. 1339). The compromise is the fractional reserve system of bank lending [70] (p. 36) that mainstream economists understand through the concept of the money multiplier. In this view, banks wait for exogenous central bank money in the form of deposits and extend it to borrowers in the form of loans, keeping a fraction as reserves in the vault should depositors wish to access their savings [68] (p. 332). The fraction of total base money that a bank holds is called the reserve ratio; its reciprocal is the money multiplier or the factor by which banks create money through the process of lending [ibid] (p. 334).

The money multiplier model of lending upholds the orthodox view of money by implying that the Central Bank:

1. Provides initial base money that savers deposit, and

2. Maintains a liquidity-ensuring reserve requirement such that banks lend a multiple of the base money up to a

3. Mathematically-defined limit equal to the reciprocal of the reserve requirement [54].

These implications rest on the assumption that banks are atomistic actors that efficiently mediate neutral commodity money between other atomistic actors (savers and borrowers) in markets that are facilitated by, but without a significant role for money [54] (p. 31). In this view the Central Bank is Hobbes' and Smith's exogenous higher power that issues base money and sets reserve requirements in order that the barter transactions below the surface [4] do not get "out of control" like Mill warned was the only way for money to cause a problem [59] (p. 341). 


\subsection{Problems with Money in Orthodox Theory}

\subsubsection{Abstract Value as Value Relation}

Walras' price numeraire as a "symbolic representation of existing commodity values" [14] (p. 18) and the subsequent orthodox conflation with a commodity that represents that symbolic representation presents a philosophical challenge. As Ingham notes, the exchange rate possibilities between even a small number of goods are insurmountable [14] (p. 25). Walras sidestepped this shortcoming by introducing his numeraire. Since a numeraire is a comparison of commodities themselves, however, the money commodity that arises to represent their relation is at once a commodity itself and a special representor of commodities [71] (pp. 15-16). This dual quality leads to considerable problems with the formulation of money's value [ibid] (p. 16), including its ability to arise as a unit of account from a medium of exchange [14] (p. 24), and its value as a relation to the community as a whole [72] (p. 177). These difficulties go far in explaining why money in orthodox theory will not have value [73] (p. 136) and must, accordingly, be treated as neutral.

Simmel escapes the logical trap that a direction comparison numeraire presents by arguing that measures need not, and most often do not, exhibit the same quality as the objects they measure [72] (pp. 131-132). Thus, money, while acting as a "stable pole" [72] (p. 121) of relative commodity values, does not represent the relation between those commodities, as a numeraire does, but rather, points to their relative relation to a third quantity [72] (p. 146). This quantity is an abstract value that constitutes a social relation and is starkly different from a "direct comparison" [ibid] of two quantities. In other words, abstract value allows for comparison, but is not the comparison itself.

Michael Hudson argues that "the essence of money is not to be sought in the material form from which it was made, but in the fact that it provided a common denominator to co-measure prices" [74] (p. 124). This co-measure is not a direct-relation numeraire, but a reference to an abstract value that allows for the orchestration of systems of debt and credit between and amongst trade merchants [75], economic agents, and the public institutions [74] (p. 117). This will be explored now.

\subsubsection{Logical and Historical Inaccuracies of Barter, and Unit of Account}

As shown above, mainstream economic theory rests on the assumption that individuals ultimately trade commodities for other commodities [76] (p. 49) and that money as a commodity-based value relation solves barter's double coincidence of wants problem. The problem is that there is "no evidence that [barter] ever happened, and an enormous amount of evidence that it did not" [30] (p. 28). As Caroline Humphrey writes, "all available ethnography suggests that there has never been such a thing [as an economic system of barter] [ . . . ] let alone the emergence from it of money" [12] (p. 49).

Logically, the barter story is also inconsistent. The idea that merchants would specialize until they held a surplus of one good while lacking all other goods is not only inconvenient, it is impossible. Seasonality and production stages further complicate the barter story [75] (p. 130). As Ingham writes: "money is logically anterior and historically prior to market exchange" [14] (p. 25). Rather than emerging as a medium of exchange from bilateral barter transactions, the evidence argues that money exists as an abstract unit of account to denominate debt relationships between merchants on alternating production cycles and between those merchants and the State [75].

A. Mitchell Innes argues that Adam Smith's oft-cited account of barter was based on a mistaken understanding of the trade dynamics in Scottish and Newfoundland villages where nails and cod were used to purchase food and supplies, respectively. While nails and cod appeared to Smith as the commodity through which barter occurred, the transactions were in fact denominated "in pounds, shillings, and pence" and were exchanged for "a credit on [the customers'] books" [77] (p. 378). What Smith believed to have been a "tangible currency" [77] (p. 378), in each situation he had found credit denominated in a unit of account enforced and upheld by the State [78] and [79] (p. 87).

A rich body of literature explores this dual state/credit nature of money as a manifestation of a complex and evolving social contract between and amongst individuals and the State. Credit theory 
argues that the barter story lacks an account of debt's role in establishing money [80] (p. 57). While Aristotle argued that commodity money solved the temporal incongruence of sales and purchases, Innes removes the tangibility of the medium and argues that a creditor's right to later payment solves the problem [78] (p. 152). For thousands of years before metallic money forms, it was these debt/credit relationships between economic actors in commodity exchange and social actors in wergild relations that formed the basis of money's nature [24] (p. 61) [30] (p. 40). While barter relations are ephemeral and asocial, Polanyi shows that economic exchanges are in fact embedded within social relations of owing and being owed [24] (p. 50). Gardiner argues that systems of credit and debt are "the foundation of [ ... ] civilization" [75] (p. 163) and come before economies themselves [75] (pp. 130, 169). Aglietta writes "wherever anthropologists have been able to discern something that we could call an economy, money existed" [15] (p. 81). Innes argued that "credit alone is money" [77] (p. 393) and forms the basis of civilization in all places and times throughout history [77] (p. 391). These views mirror the Vedic poems of the second millennia BC in which "a man, being born, is a debt" [30] (p. 56) as well as the more recent primordial debt theorists who argue that debt is, and has always been, the essence of society itself [ibid].

State theory argues that the barter story lacks an account of the State's role in establishing an abstract standard of account [80] (p. 57) to denominate the above credit/debt relationships. Whereas Locke argued that the State's role in money was to standardize weights and measures, Friedrich Knapp's chartalist theory argued that legal ordinances, not materiality, regulate money's use [81] (pp. 1-2). In the chartalist view the State plays a dual role. On the one hand it designates a unit of account to act as money by purchasing goods and services in that unit [14] (p. 12). On the other hand it drives money through its monopolization on the use of violence [82] (p. 42)-in this case the ability to collect taxes in the unit of account it has designated [83] and [84] (p. 137). It is precisely this dual role as simultaneous supplier and demander [14] (p. 12) [80] (p. 62) that prompted Silvio Gesell to write: "Money requires the State, without a State money is not possible" [85] (p. 81).

Together, the State and Credit Theories propose that money's nature as a unit of account take primacy over money's function as a medium of exchange. It is precisely here that orthodox economic models fail: they are built upon a medium of exchange and must, therefore, determine why one commodity would be chosen as a medium of exchange over all others [63] (p. 294) [86] (pp. 126-135), something they cannot do [14] (pp. 21, 24). Innes pointed out that any solution to this predicament would be an "obvious absurdity" since the chosen commodity would be denominated in itself [77] (p. 378). This is the logical circularity at the center of economic theory and why Hayek wrote "the identity of supply and demand [ ... ] ceases to exist as soon as money becomes the intermediary" [87] (p. 130). Not only can a direct commodity relation not serve as an abstract unit of account [72] (p. 132), an abstract unit of account cannot be chosen as a direct commodity relation. Drawing upon Aglietta, any privately appropriable commodity medium would undermine, by way of its very liquidity, the exogenous utility requirement at the center of equilibrium theory [15] (p. 8). Since, as argued above, a unit of account is the primary characteristic of money, it cannot exist within a model that requires a direct-relation numeraire to equilibrate. Accordingly, the Arrow-Debreu theorem's logic that money is extraneous since it can reach equilibrium without money only holds if money is understood as a medium of exchange. When money is understood as a credit-based unit of account, the model cannot reach equilibrium. Far from Schumpeter's argument that money does not affect the economic process [5] (p. 277), money itself is the economic process [15].

Pursuant to the prior two sections, this paper defines money as a unit of account in which credits and debts are denominated. This definition is important because it allows us to treat the myriad shifts between pre-economic money and modern money as major historical evolutions of a foundational social institution, rather than distinct and incomparable forms of exchange media. 


\subsubsection{Commercial Banks Create Money}

Modern money is created when commercial banks issue loans to individuals and corporations at interest $[54,58]$. This 'horizontal' money makes up approximately $97 \%$ of money in the UK [88] and approximately $92 \%$ of money in the US (data from the Federal Reserve Bank of St. Louis).

While neoclassical theory assumes that banks use customer deposits when extending loans, in practice, commercial banks generate loans by increasing a borrower's deposit account ex nihilo equal to the amount of the loan [84] (p. 84). The bank views the loan as an asset and that is offset by a deposit liability, while the borrower views the loan as a liability that is offset by a deposit asset. The process is that simple: there was no need for a savings deposit before extending the loan and banks will extend all the loans they deem profitable regardless of deposits.

This "fountain pen money" [70] (p. 37) enters circulation when borrowers spend their credit in the economy [54] (p. 61). If a borrower spends their credit with a customer of the same bank, a simple balance sheet operation between the customers will clear the payment. Otherwise, commercial banks use one of two kinds of Central Bank Money to clear their customers' payments: Central Bank reserves or cash [58] (p. 77).

If a borrower spends their credit with a customer of a different bank, the respective banks will exchange reserves to clear the payment. Reserves are created ex nihilo by the Central Bank in order to facilitate payments between intra-bank customers and can only be accessed by commercial banks. At the end of each day, commercial banks net their incoming and outgoing reserve positions and borrow any owed reserves from either the Central Bank or the interbank lending market.

If a borrower wishes to spend their credit without the use of a bank intermediary, they may withdraw cash. Commercial banks acquire cash from the Central Bank in exchange for reserves. While some of this cash can be retained by banks to satisfy their withdraw demands, all cash ultimately begins as a loan [58] (p. 103) and can thus be seen as a "physical representation of commercial bank money" [54] (p. 72).

This dynamic contradicts the neoclassical view of banking and explains why Mervyn King, former Governor of the Bank of England, argues that "money is endogenous [ ... ] [to] the banking system" [58] (p. 78). Endogeneity challenges the three implications of neoclassical theory.

1. Banks do not wait for deposits before making loans. Cash and reserves are always created in response to lending activity [54] (p. 103) [89] (p. 49).

2. Reserve requirements do not limit lending to a multiple of base money that is kept in the bank's vault [68] (p. 333); they create cash and reserves as a fraction of total lending, ex post, to enable liquidity between banks and individuals. A fractional reserve system does not exist.

3. Banks will always extend loans if there is a positive interest spread between the loans and the Central Bank Money needed to ensure payments clear.

\subsection{Orthodox Monetary Theory and Policy as Atomistic Ontology}

Money is a blind spot for orthodox theory due, largely, to the atomistic ontology at its core. Money's treatment as a neutral, commodity-based medium of exchange within a barter economy is a direct descendent of Aristotle's economic theory [90] (p. 174) and the hierarchical dualism implicit in his philosophy and its interpretation and development through time. On the one hand, atomism implies that commercial banks allocate a limited supply of money, like any other commodity, amongst consumers (investors) and producers (savers) around the price (interest) mechanism while the exogenous Central Bank maintains equilibrium. On the other hand, atomism drives assumptions about money's nature as a representation of barter between individual utility maximizers [14] (p. 22).

Since a barter economy cannot be distinguished from an economy using commodity money [91] (p. 3), the application of orthodox barter theory must use commodity money and view banking as an intermediary. As we have seen, however, commodity money has never existed and banks are not commodity lenders [92] (p. 256). Money is a unit of account to denominate credit and banks are credit 
creators who play a deterministic role in the quality and quantity of money in the economy. Such a money economy is structurally different from a barter economy [72] (p. 178) and is utterly incompatible with the methodology of orthodox neoclassical economics" [14] (p. 21) that equilibrates around price rather than money.

For these reasons, mainstream economists must either deny the existence of endogenous money like Krugman [66], or argue for a monetary policy that creates the fictitious conditions for a material money like Hayek [87] (p. 130) and Lutz [93] (p. 115). It is this paper's argument that integrating the social dynamics of debt that are inherent in money itself, and assigning power and interdependence (socially and ecologically) in the monetary lifecycle, would undermine the neutral-commodity concept that is central to "the entire discourse of economics" [30] (p. 43) from both the micro and macro perspectives. From a micro perspective, money that does not represent a barter commodity distorts the fundamentals of market equilibrium, as we have seen [15] (pp. 19-22). From a macro perspective, endogenous money undermines the IS-LM model where "loanable funds" generate investment in an economy [44]. Since creating the conditions for the economy to operate like the neoclassical model would mean redesigning much of human history [63], it is prudent, rather, to "alter the model in a fundamental way" to include money [73] (p. 136).

\subsection{Problems with Private Money Creation}

Modern money is a manifestation of the dualism implicit in Western culture. However, due to the neutrality at the center of the orthodox model, problems attendant to money are assumed to be temporary and not structural. Money, however, is not neutral [92] (p. 159). It follows, then, that the social optimality at the center of the neoclassical model will always be undermined and the system can only ever be, in Mill's words, "out of control" [59] (p. 341). While on the surface, the difference between credit-based unit of account and a barter-centric medium of exchange may seem trite, the monetary system resultant to that difference is at the foundation of our economic, social, and ecological problems.

As Minsky argues, an endogenous money system is inherently unstable due to the cyclicality it embodies [94]. Since the vast majority of money in circulation exists as a function of bank profit, attempts to stabilize the economy have largely proven inefficacious [58] (pp. 95-109). Government response to such cyclicality tends often to force growth, eliminate regulation, and fund profitable rather than desirable business [58] (pp. 161-162).

Further, since exogenous money must generate enough profits to cover principal and interest, socially-and ecologically-harmful activities are prioritized over sufficiency activities that are cost- rather than profit-based [95]. Socially, credit-based money systematically transfers wealth from borrowers and renters to lenders and rentiers [7] (p. 161). This is especially true when investment returns outpace economic growth [96]. Sociologist Michael Mann argues that money's usefulness as a facilitator of cooperation across space can be appropriated by particular interests that control, not only the quantity of money, but more importantly, its production [14] (p. 4).

Ecologically, since debt-based money must always grow [97,98], heavy strain is put on ecosystems to continually produce goods lest the economy crash. This problem is not unique to goods since services also, necessarily, have a physical dimension [11] (p. 412). While for Locke, money's durability eschewed the limits of his proviso, Soddy [10] and Gesell [85] were both concerned with the entropic contradiction of an abstraction that commands physical resources.

\section{Ecological Economics}

\subsection{Ecological Economics}

Ecological Economics provides an alternative to orthodox economic thought by offering a theoretical critique of equilibrium theory while embedding the economy within a biophysical reality. The field views humans as other-regarding social animals with interests outside of selfish utility maximization [99] (p. 1224) [100]. Accordingly, it holds that the axioms of consumer choice that 
form the backbone of neoclassical theory break down as social systems co-evolve with ecological systems [40] (p. 109) [101]. Ecological economics also argues that the price mechanism is an ineffective feedback loop [102], especially for the vast array of non-market goods and services [103] (p. 35).

Outside of its behavioral-mathematical critique, ecological economics embeds the economy within the biosphere [104] (p. 50) by contending that economic processes are energetic processes that are subject to entropy [8]. While mainstream economics views the economy as a circular exchange relationship between firms and individuals, ecological economics is concerned with resource inputs and waste outputs [105] and the qualitative transformations of commodities in its understanding of the economy [11] (p. 35).

Ecological economics is also a normative discipline in which ethical considerations are made explicit [106] (p. 46). Daly argues that resources should be depleted on grounds of "ethical desirability" rather than profitability [107]. Brown and Erickson argue that "the foundations of both political and economic liberalism must be rethought from the ground up" [108] (p. 46). The field thus aligns well with the ontological presuppositions of ecofeminism [109] and its critique that modern economies are dualized in ways that fail to adequately acknowledge the labor and resources upon which they rest [47] (p. 54). A special edition of the journal considered this alignment by exploring the dualistic behavioral assumptions of equilibrium theory [1], the subject/object dualism implicit in production theory [110], and the social and ecological destructiveness of a dualized economic theory [111] (p. 164). Ecological economics has not broadly, however, addressed these dualisms [112]; specifically, how they manifest in orthodox monetary theory and therefore in the field's own understanding of, and approach to, money.

\subsection{Money: Ecological Economics' Blindspot}

As a transdisciplinary school, ecological economics draws upon other disciplines [39] in order to address "the substantive failures of orthodox economics" [106]. This paper uses sociology, geography, anthropology, and ecofeminism in order to address what I contend is the central failing of the neoclassical model: the notion that money is a neutral outcropping of barter trade.

While ecological economics certainly understands the importance of money generally [10] (ch. 7, p. 2) [113] (p. 91) and money creation specifically [11] (p. 407) [114], it has nevertheless largely ignored monetary theory [115] (p. 258). Accordingly, the field makes two mistakes. First, it misses the most central critique of neoclassical school: that barter exchange is structurally distinct from money exchange. Since even "the best model of the economy cannot find room for [money]" [86] (p. 1) without a monetary theory, ecological economics risks, like the orthodox school, assuming either that money does not matter or that its analysis can come after economic theory. Second, by failing to develop a theory of money for itself, ecological economics has borrowed from other disciplines, causing errors (the barter myth) and inconsistencies (ontological overlap) in its analysis, to be explored, respectively, now.

\subsubsection{The Barter-Commodity Myth In Ecological Economics}

The introductory text by Farley and Daly explains that individuals hold money in order "to avoid the inconvenience of barter" [116] (p. 288). Daly writes in For the Common Good that "barter [ ... ] is the simplest and oldest method of exchange" [11] (p. 409). While Daly and Farley now reject this view, as a field, the barter-commodity myth persists. Lawn writes that "money [ ... ] allows you to overcome the inconvenience [ ... ] of bartering" [117] (p. 932). Roma uses an energy-numeraire money to develop a thermodynamic production equilibrium, arguing that commodity money has been the economic standard for thousands of years [118] (p. 544).

In fact, the journal does not, to my knowledge, contain a single article that challenges the barter myth [119]. It is my explicit argument that, since an economic system of barter has never existed, failing to challenge the idea of barter risks implicitly integrating a commodity numeraire into theory and ignoring the critical role of money in the economy. Further, failing to understand the role that 
states and corporations play in establishing a monetary system while ignoring the intricate relationship between gendered socio-ecological power dynamics, debt, and money [47] (p. 132) [80] (p. 57) has significant implications for any conclusions that may be drawn from an analysis of money.

Resultant to the barter myth, Daly writes that "banks cannot create money under $100 \%$ reserves [since] the reserve deposit multiplier would be unity" [120]. In fact, banks can create money under $100 \%$ reserves, especially if all banks move in lockstep [121] and/or the banking industry is dominated by a few large banks [54] (p. 68) [58] (p. 99).

My goal here is neither to criticize Daly nor to be trite over word choice. It is to argue that a multiplier unity assumes that banks lend savings and ultimately rests upon an understanding of banks as intermediaries between bilateral barter exchanges. Daly's argument, as he clearly articulates, is that banks cannot create money when banking is separated into deposit holding and savings lending [122] (p. 9). It is therefore not the reserve requirement that limits money creation. It is (1) the separation of banking activities [14] (p. 114), and (2) the requirement that savers and borrowers cannot use the same money at the same time [123] (p. 19). While this distinction may seem small, the policy implications between reserve requirements and separate banking activities are radical.

\subsubsection{The Weakness of a Post-Keynesian/Ecological Economic Monetary Synthesis}

Ecological economics' lack of a foundational monetary theory means that the school has long drawn on a post-Keynesianism monetary framework "given [the schools'] methodological overlap" [124] (p. 182). This is especially true of Jackson and Victor [125] and Miller [126]. The reverse is also true, with post-Keynesians such as Fontana and Sawyer [127] and Lavoie and Cahen-Fourot [128] publishing monetary pieces in the journal.

This synthesis, however, should be undertaken with caution as it "leaves unanswered how scientific progress is meant to be achieved" [106] (p. 42), and fails to incorporate ontology and epistemology [ibid] (p. 45), deferring instead to methodology alone. By integrating the work of other disciplines, one implicitly ascribes to their ontological and epistemological presuppositions. Miller argues that while there are some frictions regarding growth and scarcity between post-Keynesianism and ecological economics, those "ought not [ ...] stand in the way of [ ...] [a] monetary synthesis" [126] (p. 14). This conflates methodology with ontology and epistemology and fails to recognize that if those frictions are a function of conflicting ontologies or epistemologies, we should be justified in our skepticism of the progress we draw from works with which we might otherwise methodologically agree (for example $[69,128]$ ).

This chasm can be seen in Rezai and Stagl's argument that by drawing from post-Keynesianism, ecological macroeconomics "has made significant progress [ ... ] [in] understanding [ ... ] current macroeconomics" [124] (p. 182). It is certainly true that post-Keynesians understand money in a productive capitalistic economy very well. Ecological economics broadly, and this paper specifically, however, argue for an ontology that runs counter to a productive capitalistic economy. Our progress should be measured as much by our understanding of how macroeconomies do work as by how they should work. Perhaps those who propose a "post-Keynsian ecological macroeconomics" [127] while labeling some in our field "monetary cranks" [69] (p. 1346) do not distinguish between "analytical errors" [ibid] (p. 1346) and epistemological difference.

Lavoie and Cahen-Fourot's [128], and Jackson and Victor's [125] consideration of capitalistic money in a steady state economy further highlights this difference. Each of their models implicitly define a steady state quantitatively rather than qualitatively, an energetic distinction that ecological economics is eager to draw [8] (p. 350). Similarly, both models fail to integrate the "distributional issues" [128] (p. 167) of a system of private money creation and "capital accumulation" [ibid] (p. 167). For example, stock-flow consistent methodology fails to draw a distinction between those who own assets and owe liabilities [14] (p. 81). Further, each model requires that banks do not accumulate profits in the course of their credit creation, a requirement that runs counter to the profit motive behind commercial bank lending in the first place [90] (pp. 107, 197). Since the ultimate goal of a steady state 
is not capital accumulation, both models prove by contradiction what they claim to have disproven by methodology, i.e., since a steady state that uses capitalist money cannot be capitalist, a steady state cannot exist with capitalist money.

Accordingly, the relationship between our schools should be one of synthesis rather than transplant. This is not to say that post-Keynesian economists are wrong or that ecological economics should not draw on the discipline. They are not and I do-especially Wray [129]. But ecological economics requires a monetary theory of its own, rooted in its own explicit ideology. Where there is overlap, it should be welcomed. Where there is friction-in either ontology or epistemology-ecological economics must stand on its own as a school of monetary thought.

\subsection{The Sociality of Money}

Odum [130] and Røpke [9] (p. 296) have each drawn upon process philosophy to argue that the closed nature of the Walrasian model fails to incorporate the fact that economic processes are ultimately ecological processes. Exending this argument, economic processes are also social processes, drawing from and contributing to the social context within which they find themselves. Ecological economics has existed thus far in a largely energetic-biophysical conception. While many examples exist [131-134] —and notwithstanding the ever-present goal of just distribution — the field has not incorporated writ large the social embeddedness of economic processes. This is especially true in the case of money, the most social of all human inventions [135] (p. 47).

Money is more fundamental and ubiquitous than any institution on the planet. Research suggests that it shaped our cognitive processes and gave rise to literacy, mathematics, and sedentary community [63]. Ingham writes that "monetary systems are the result of the long term historical development of a complex structure of social relations" [13] (p. 516). Simmel argues that money is a claim upon society [72] (p. 176). Money is quite literally the institution upon which society rests.

Accordingly, any attempt to consider social policy—and by extension, environmental policy-in isolation from monetary policy will fail because, as primordial debt theorists argue, they "have always been the same thing" [30] (p. 56). Many of the shortcomings of ecological economics' approach to money, and the school's inefficacy in influencing policy or discourse in a meaningful way, can be resolved if money is defined as a unit of account and "conceptualized as a structure of social relations" [13] (p. 507). As said before, failing to do so traps ecological economics in either the (1) "economic principles first, money second" camp, or the (2) "money is a value numeraire" camp.

The dearth of import that Ecological Economics assigns to the topic of money generally, but to its sociality especially, is exemplified by the fact that neither A. M. Innes nor Friedrich Knapp are ever mentioned or cited in the journal's history. (Notably, Mellor [47,135] Dittmer [136,137] do cite these authors in other journals.) Geoffrey Ingham is mentioned once [122], and Georg Simmel and Michel Aglietta are mentioned in the context of social order and capitalism, respectively, but never money. Among others, these thinkers form the indispensable backbone of monetary theory.

\subsection{The Gendered Basis of Money}

Neoclassical economic theory inferiorizes resource and labor inputs. While ecological economics has been largely rooted in its critique of the former, the latter, especially vis-à-vis gender, is a complementary critique without which the former falls short [18] (p. 13). Accordingly, much like ecological economics has not fully explored the social embeddedness of economic systems, it has not fully explored the gendered dualization of those systems. Mellor argues that ecological economics' critique "would be greatly enhanced if it were to recognize the links between the [ ... ] exploitation of the natural world and women's labor" [134] (p. 122). This is especially true in the case of money.

As explored above, money forms the foundation for society itself [77] (p. 391) and represents an individual's claim upon society [72] (p. 176). In a hierarchically gendered society, however, domestic and communal work is largely excluded from the money sphere [70] (p. 158) and the social claims that entails. From an ecological perspective, money is a license to extract resources [113] (p. 78) [138] 
(p. 141). Again, in a dualized society, resources fail to reflect the gendered reproductive and cyclical labor explicit in their extraction.

Much like its broader critique has existed largely in a biophysical realm, ecological economics has heretofore attempted to understand money from the perspective of entropy $[10,11,64]$. However, since money is "brought into being through a combination of private, public and social acts [and becomes] a claim on resources and labour" [70] (p. 159), the gendered dynamic of the labor embodied in those social and ecological dynamics must be equally considered [139] (p. 255). Without doing so, Mellor further argues, "ecological economics risks importing gendered assumptions into its theories and proposals" [134] (p. 122).

\section{An Ecological Monetary Theory}

Since money is a social relationship that forms the basis of human civilization [15] (pp. 39-40) [75] (p. 163), ecological economics must develop a foundational theory of money upon which alternative economic theory and subsequent social and environmental policy may rest. And since, as we have seen, orthodox monetary theory and mainstream monetary policy is rooted in a dualized social and environmental relationship, an ecological monetary theory should be rooted in an alternative to that dualism. Accordingly, this paper argues for three requirements of an ecological monetary theory: reject the barter myth, articulate money as a social relation of debts and credits, and adopt an ontology in which hierarchical dualisms amongst and between humans and nature are eliminated. Such an approach aligns well with Ingham's call for an "ontology of money" [13] (p. 509). It also provides an effective tool through which ecological economics can examine policy and policy alternatives without implicitly adopting the ontological presuppositions of other theories. As of this writing, this has not been done.

Spash argues that "consumer theory should be consistent with human behavior and production theory should be consistent with biophysical laws" [133] (p. 357). I extend his argument here, positing that since human behavior is embedded within an ultimately debt-based sociality [15] (p. 39), and money is a dualist claim on biophysical resources [139] (p. 255), an ecological monetary theory should form the basis of ecological economics' consumer and producer theories. As Aglietta writes, "if we consider the economy as a subset of social relations," something ecological economics explicitly does, "then we need a political economy founded on money" [15] (p. 5).

Moreover, if ecological economics bases its macroeconomic theory in monetary theory, it will have a strong base upon which to address current macroeconomic issues such as finance, distribution, and welfare [124] (pp. 182-184), where the opposite is not true. Accordingly, ecological monetary theory and ecological macroeconomics should not be confused. Rezai and Stagl [124] (p. 183) make this mistake when presenting the nature of money as the debate between exogeneity and endogeneity, rather than an exploration of money's nature as a unit of account to denominate credit [14]. Further, ecological monetary theory should not be understood as a subset of ecological macroeconomics, as Lavoie and Cahen-Fourot contend [128] (p. 163), but as a foundation of both ecological microand macroeconomics.

The case of modern money is an example of why rooting economic theory in monetary theory is prudent. Modern money can be understood as a merger of the State and Credit Theories wherein the vast majority is created by commercial banks when they extend credit that is denominated in the State's hegemonic unit of account and facilitated by fiat Central Bank money [80] (p. 65). While this contradictory existence has been at the core of monetary economies for thousands of years, it is currently the result of the tension between the orthodox commodity theory of money on the one hand, and the complex social nature of money on the other. Addressing this contradiction requires us to understand that modern money is indeed money, but is also a reflection of our socio-ecological values [90] (p. 183). Thus, while Knapp argued that it is the acceptance, not the issuance, that defines money [81] (p. 95), ecological monetary theory can add that since issuance reflects our values, how we create and spend money should form the base of how ecological economics' micro and macro theories 
will articulate consumption, production, inequality, and growth. As Ingham writes, "once money has been produced, then economic analysis is applicable" [14] (p. 198).

An ecological monetary theory must therefore exist somewhere between a critique of modern private-debt money on the one hand, and an acceptance of the social-debt money that has existed for thousands of years on the other. In other words, critiquing modern money on the basis of its existence as a credit/debt relationship fails to integrate the fact that all money in all times has existed that way [30] and [75] (p. 163) [78]. This space is filled by an explicit differentiation between public and private credit and debt, and the ontological presuppositions that come with that differentiation. Articulating public debt as social equity [140], for example, may bridge this critique-acceptance gap.

A non-dualized ecological monetary theory based in an historical understanding of money's origin as debt, could form the foundation of an economy that is consistent with the pre-analytical vision of ecological economics. This would strongly contrast the fundamentally unstable modern money supply and support Douthwaite's idea of a money system that continues to function in the absence of growth [98] (p. 27). It could also articulate the quality of money in circulation as well as its quantity. Further, it allows us to address the biophysical problems that sociological theory does not, and the social problems that a biophysical theory cannot. Finally, an ecological monetary theory can act as a filter through which past, current, and proposed monetary systems, as well as their respective critiques, may be considered.

\section{Conclusions}

Western culture is dualized in a way that justifies the subordination of nature and women. This dualization leads to an economic theory that is atomistic and mechanistic, and, accordingly, must treat money as a neutral reflection of barter. In reality, however, money is historically the most social institution on the planet and modern money is created according to dualistic power structures.

Ecological economics offers an alternative to mainstream economics that embeds the economy in the biosphere. Since it has not critiqued the dualism at the center of the mainstream model, however, it lacks the gender critique that is the environmental critique's necessary complement. And while the school has argued that money is a critical issue, failing to address dualism risks incorporating the barter myth into its own analysis and treating money as secondary to economic theory.

This paper has argued that since money forms the basis of civilization, economic theory should be rooted in monetary theory. Moving forward, ecological economics must develop an ecological monetary theory that is rooted in an understanding of money's socio-history and explicitly addresses the dualistic nature of Western socioeconomic and monetary systems.

Funding: This research was supported by the Economics for the Anthropocene project. It was funded by The Social Science and Humanities Research Council of Canada; Gund Institute for Environment at The University of Vermont; and The Rubenstein School of Environment and Natural Resources at The University of Vermont.

Acknowledgments: I would like to thank Ole Bjerg, Pablo Bose, Peter Brown, Ben Dyson, Jon Erickson, Joshua Farley, Brendan Fisher, John Fullerton, Joseph Huber, Mary Mellor, Ellie Perkins, Joshua Ryan-Collins, and Romain Svartzman for their inspiration—-known or not—-throughout the inception and creation of this paper. All mistakes are mine alone.

Conflicts of Interest: The author declares no conflict of interest. The funders had no role in this research or writing.

\section{References and Note}

1. Mellor, M. Women, nature and the social construction of 'economic man'. Ecol. Econ. 1997, 20, 129-140. [CrossRef]

2. Gaard, G. Ecofeminism: Women, Animals, Nature/Edited by Greta Gaard; Temple University Press: Philadelphia, PA, USA, 1993; ISBN 978-0-87722-988-9.

3. Merchant, C. The Death of Nature: Women, Ecology, and the Scientific Revolution; Reprint edition; Harper One: New York, NY, USA, 1990; ISBN 978-0-06-250595-8. 
4. Samuelson, P. Economics: The Original 1948 Edition, 1st ed.; McGraw-Hill Education: New York, NY, USA, 1948; ISBN 978-0-07-074741-8.

5. Schumpeter, J.A. History of Economic Analysis; Allen \& Union: London, UK, 1954.

6. Dyson, B.; Greenham, T.; Ryan-Collins, J.; Werner, R. Towards a Twenty-First Century Banking and Monetary System, Submision to the Independent Commission on Banking; Independent Commission on Banking: London, UK, 2011.

7. Michel, A.; Hudon, M. Community currencies and sustainable development: A systematic review. Ecol. Econ. 2015, 116, 160. [CrossRef]

8. Georgescu-Roegen, N. Energy and Economic Myths. South Econ. J. 1975, 41, 347-381. [CrossRef]

9. Røpke, I. The early history of modern ecological economics. Ecol. Econ. 2004, 50, 293-314. [CrossRef]

10. Soddy, F. Wealth, Virtual Wealth and Debt the Solution of the Economic Paradox; Omni: Seattle, WA, USA, 1930.

11. Daly, H. For the Common Good: Redirecting the Economy toward Community, the Environment, and a Sustainable Future/Herman E. Daly and John B. Cobb, Jr.; with Contributions by Clifford W. Cobb, 2nd ed.; updated and expanded; Beacon Press: Boston, MA, USA, 1994; ISBN 978-0-8070-4705-7.

12. Humphrey, C. Barter and Economic Disintegration. Man 1985, 20, 48-72. [CrossRef]

13. Ingham, G. Money is a Social Relation. Rev. Soc. Econ. 1996, 54, 507-529. [CrossRef]

14. Ingham, G. The Nature of Money, 1st ed.; Polity: Cambridge, UK; Malden, MA, USA, 2004; ISBN 978-0-7456-0997-3.

15. Aglietta, M. Money: 5000 Years of Debt and Power; Verso: London, UK; New York, NY, USA, 2018; ISBN 978-1-78663-441-2.

16. Corner, E.J.H. The Durian Theory or the Origin of the Modern Tree. Ann. Bot. 1949, 13, 367-414. [CrossRef]

17. Mellor, M. Gender and the Environment. In The International Handbook of Environmental Sociology; Redclift, M., Woodgate, G., Eds.; Edward Elgar: Cheltenham, UK; Northampton, MA, USA, 1997; ISBN 978-1-85898-405-6.

18. Plumwood, V. Feminism and the Mastery of Nature/Val Plumwood; Opening out; Routledge: London, UK; New York, NY, USA, 1993; ISBN 978-0-415-06809-3.

19. Warren, K. The power and the promise of ecological feminism. Environ. Ethics 1990, 12, 125. [CrossRef]

20. Plato. Timaeus and Critias; Johansen, T.K., Ed.; Revised edition; Penguin Classics: London, UK, 2008; ISBN 978-0-14-045504-5.

21. Plato. Phaedo; Arc Manor: Kittanning, PA, USA, 2008; ISBN 978-1-60450-310-4.

22. Kheel, M. From Heroic to Holistic Ethics: The Ecofeminist Challenge. In Ecofeminism: Women, Animals, Nature, 1st ed.; Gaard, G., Ed.; Temple University Press: Philadelphia, PA, USA, 1993.

23. Bordo, S. The Cartesian Masculinization of Thought. Signs 1986, 11, 439-456. [CrossRef]

24. Polanyi, K. The Great Transformation: The Political and Economic Origins of Our Time, 2nd ed.; Beacon Press: Boston, MA, USA, 2001; ISBN 978-0-8070-5643-1.

25. Li, H. A Cross-Cultural Critique of Ecofeminism. In Ecofeminism: Women, Animals, Nature, 1st ed.; Gaard, G., Ed.; Temple University Press: Philadelphia, PA, USA, 1993.

26. Donovan, J. Animal Rights and Feminist Theory. In Ecofeminism: Women, Animals, Nature, 1st ed.; Gaard, G., Ed.; Temple University Press: Philadelphia, PA, USA, 1993.

27. Kenny, A. Anatomy of the Soul: Historical Essays in the Philosophy of Mind, 1st ed.; Blackwell Publishers: Oxford, UK, 1973; ISBN 978-0-631-14960-6.

28. Beauvoir, S. The Second Sex, 1st ed.; Random House: New York, NY, USA, 1968; ISBN 978-0-307-27778-7.

29. Keen, S. Debunking Economics—Revised and Expanded Edition: The Naked Emperor Dethroned? 2nd ed.; Zed Books: London, UK, 2011; ISBN 978-1-84813-992-3.

30. Graeber, D. Debt: The First 5000 Years; Upd Exp edition; Melville House: New York, NY, USA, 2014; ISBN 978-1-61219-419-6.

31. Linklater, A. Owning the Earth: The Transforming History of Land Ownership; Reprint edition; Bloomsbury: New York, NY, USA, 2015; ISBN 978-1-62040-291-7.

32. Locke, J. Two Treatises of Government: With a Supplement, Patriarcha, by Robert Filmer; Simon and Schuster: New York, NY, USA, 1947; ISBN 978-0-02-848500-3.

33. Brown, P. Democracy in the Anthropocene; Center for Humans \& Nature: Chicago, IL, USA, 2013.

34. Shiva, V.; Mies, M. Ecofeminism; Zed Press: London, UK, 1993; ISBN 978-1-895686-28-9.

35. Norgaard, R.B. The case for methodological pluralism. Ecol. Econ. 1989, 1, 37-57. [CrossRef]

36. Nadeau, R.L. The unfinished journey of ecological economics. Ecol. Econ. 2015, 109, 101-108. [CrossRef] 
37. Jevons, W.S. The Theory of Political Economy, 2nd ed.; Macmillan: London, UK, 1879.

38. Farley, J.; Schmitt, A.; Burke, M.; Farr, M. Extending market allocation to ecosystem services: Moral and practical implications on a full and unequal planet. Ecol. Econ. 2015, 117, 244-252. [CrossRef]

39. Gowdy, J.; Erickson, J.D. The approach of ecological economics. Camb. J. Econ. 2005, 29, 207-222. [CrossRef]

40. Gowdy, J. Microeconomic Theory Old and New: A Student's Guide; Stanford University Press: Redwood, CA, USA, 2009; ISBN 978-0-8047-7285-3.

41. Keynes, J.M. The General Theory of Employment, Interest, and Money; Palgrave Macmillan: London, UK, 1936; ISBN 978-1-987817-80-5.

42. Hicks, J.R. Keynes and the "Classics"; A Suggested Interpretation. Econometrica 1937, 5, 147. [CrossRef]

43. Friedman, M. The Marshallian Demand Curve. J. Political Econ. 1949, 57, 463-495. [CrossRef]

44. Krugman, P. IS-LMentary. In The Conscience of a Liberal; The New York Times: New York, NY, USA, 2011.

45. Foster, J.B.; York, R.; Clark, B. The Ecological Rift: Capitalism's War on the Earth; Monthly Review Press: New York, NY, USA, 2011; ISBN 978-1-58367-218-1.

46. Jochimsen, M.; Knobloch, U. Making the hidden visible: The importance of caring activities and their principles for any economy. Ecol. Econ. 1997, 20, 107-112. [CrossRef]

47. Mellor, M. Debt or Democracy: Public Money for Sustainability and Social Justice; Pluto Press: London, UK, 2015; ISBN 978-0-7453-3554-4.

48. Ims, K.J.; Jakobsen, O.D.; Zsolnai, L. Product as process-Commodities in mechanic and organic ontology. Ecol. Econ. 2015, 110, 11-14. [CrossRef]

49. Brown, P.G. Toward an economics of stewardship: The case of climate. Ecol. Econ. 1998, 26, 11-21. [CrossRef]

50. Lawson, T. What is this 'school' called neoclassical economics? Camb. J. Econ. 2013, 37, 947-983. [CrossRef]

51. Chapman, A. Barter as a Universal Mode of Exchange. L'Homme 1980, 20, 33-83. [CrossRef]

52. Boulding, B. Evolutionary Economics/Kenneth E. Boulding; Sage Publications: London, UK, 1981; ISBN 978-0-8039-1648-7.

53. Cirillo, R. Leon Walras' Theory of Money. Am. J. Econ. Sociol. 1986, 45, 215-221. [CrossRef]

54. Ryan-Collins, J.; Greenham, T.; Werner, R.; Jackson, A. Where Does Money Come From?: A Guide to the UK Monetary \& Banking System, 2nd ed.; New Economics Foundation: London, UK, 2012; ISBN 978-1-908506-23-8.

55. Varian, H. Intermediate Microeconomics: A Modern Approach, 9th ed.; W. W. Norton \& Company: New York, NY, USA; London, UK, 2014; ISBN 978-0-393-12396-8.

56. Meikle, S. Aristotle on Money. Phronesis 1994, 39, 26-44. [CrossRef]

57. Smith, A. An Inquiry into the Nature and Causes of the Wealth of Nations/Adam Smith; General Editors R. H. Campbell and A. S. Skinner; Textual Editor W. B. Todd; Glasgow Edition of the Works and Correspondence of Adam Smith; Clarendon Press: Oxford, UK, 1976; ISBN 978-0-19-828184-9.

58. Jackson, A.; Dyson, B. Modernising Money: Why Our Monetary System Is Broken and How It Can Be Fixed; Positive Money: London, UK, 2012; ISBN 978-0-9574448-0-5.

59. Mill, J.S. Principles of Political Economy; Penguin Books: London, UK, 1974; ISBN 978-0-14-040017-5.

60. Say, J.B. A Treatise on Political Economy: Or The Production, Distribution, and Consumption of Wealth; Augustus M Kelley Publishers: New York, NY, USA, 1852.

61. Samuelson, P.A. An Exact Consumption-Loan Model of Interest with or without the Social Contrivance of Money. J. Political Econ. 1958, 66, 467-482. [CrossRef]

62. Wheelan, C.; Malkiel, B.G. Naked Economics: Undressing the Dismal Science; Fully Revised and Updated edition; W. W. Norton \& Company: New York, NY, USA, 2010; ISBN 978-0-393-33764-8.

63. Martin, F. Money: The Unauthorized Biography_From Coinage to Cryptocurrencies; Vintage: New York, NY, USA, 2015; ISBN 978-0-345-80355-9.

64. Zencey, E. Fixing Locke: Civil Liberties on a Finite Planet; White Paper; Empire State College: Saratoga Springs, NY, USA, 2009.

65. Mankiw, N.G. Macroeconomics/N. Gregory Mankiw, 8th ed.; Worth: New York, NY, USA, 2013; ISBN 978-1-4292-4002-4.

66. Krugman, P. Banking Mysticism. In The Conscience of a Liberal; The New York Times: New York, NY, USA, 2012.

67. Krugman, P. Minsky and Methodology (Wonkish). In The Conscience of a Liberal; The New York Times: New York, NY, USA, 2012. Available online: https:/ / krugman.blogs.nytimes.com/2012/03/27/minksyand-methodology-wonkish/ (accessed on 5 February 2019). 
68. Mankiw, N.G. Macroeconomics, 6th ed.; Worth Publishers: New York, NY, USA, 2008; ISBN 978-1-4292-4002-4.

69. Fontana, G.; Sawyer, M. Full Reserve Banking: More 'Cranks' Than 'Brave Heretics'. Camb. J. Econ. 2016, 40, 1333-1350. [CrossRef]

70. Mellor, M. The Future of Money: From Financial Crisis to Public Resource; Pluto Press: London, UK; New York, NY, USA, 2010; ISBN 978-0-7453-2995-6.

71. Dodd, N. The Sociology of Money: Economics, Reason \& Contemporary Society, 1st ed.; Continuum Intl Pub Group: New York, NY, USA, 1994; ISBN 978-0-8264-0637-8.

72. Simmel, G. The Philosophy of Money, 3rd ed.; Routledge: Abingdon, UK; New York, NY, USA, 2004; ISBN 978-0-415-61011-7.

73. Ritter, J.A. The Transition from Barter to Fiat Money. Am. Econ. Rev. 1995, 85, 134-149.

74. Hudson, M. The Archaeology of Money: Debt vs. Barter Theories of Money's Origins. In Credit and State Theories of Money: The Contributions of A. Mitchell Innes; Wray, L.R., Innes, A.M., Eds.; Edward Elgar Pub: Cheltenham, UK; Northampton, MA, USA, 2004; ISBN 978-1-84376-513-4.

75. Gardiner, G. The primacy of trade debts in the development of money. In Credit and State Theories of Money: The Contributions of A. Mitchell Innes; Wray, L.R., Ed.; Edward Elgar Pub: Cheltenham, UK; Northampton, MA, USA, 2004; ISBN 978-1-84376-513-4.

76. Madrick, J. Seven Bad Ideas: How Mainstream Economists Have Damaged America and the World; Knopf Doubleday Publishing Group: London, UK, 2014; ISBN 978-0-307-95072-7.

77. Innes, A.M. What is money? Bank. Law J. 1913, 30, 151-168.

78. Innes, A.M. Credit theory of money. Bank. Law J. 1914, 31, 377-408.

79. Fayazmanesh, S. Money and Exchange: Folktales and Reality, 1st ed.; Routledge: London, UK, 2012; ISBN 978-0-415-65563-7.

80. Bjerg, O. How is Bitcoin Money? Theory Cult. Soc. 2016, 33, 53-72. [CrossRef]

81. Knapp, G.F. The State Theory of Money; Macmillan \& Co.: London, UK, 1924; ISBN 978-1-61427-496-4.

82. Harvey, D. Seventeen Contradictions and the End of Capitalism; Reprint edition; Oxford University Press: Oxford, UK, 2015; ISBN 978-0-19-023085-2.

83. Ruml, B. Taxes For Revenue Are Obsolete. Am. Aff. 1946, VIII, 35-39.

84. Wray, L.R. Modern Money Theory: A Primer on Macroeconomics for Sovereign Monetary Systems, 2nd ed.; Palgrave Macmillan: Basingstoke, UK; New York, NY, USA, 2015; ISBN 978-1-137-53990-8.

85. Gesell, S. Establishing a Natural Economic Order Through Free-Land and Free-Money by Silvio Gesell: A Founder of the 1919 Bavarian Soviet Republic; The Edwin Mellen Press: Lewiston, NY, USA, 1929; ISBN 978-0-7734-1574-4.

86. Hahn, F. Money and Inflation; Basil Blackwell Publisher: Oxford, UK, 1981.

87. Hayek, F.A. Prices and Production; Studies in Economics and Political Science, No. 107; GRoutledge \& Sons, Ltd.: London, UK, 1935.

88. McLeay, M.; Radia, A.; Thomas, R. Money Creation in the Modern Economy; Bank of England Quarterly Bulletin: London, UK, 2014.

89. Mellor, M. Money as a Public Resource for Development. Development 2012, 55, 45-53. [CrossRef]

90. Ingham, G. The Emergence of Capitalist Credit Money. In Credit and State Theories of Money: The Contributions of A. Mitchell Innes; Wray, L.R., Innes, A.M., Eds.; Edward Elgar Pub: Cheltenham, UK; Northampton, MA, USA, 2004; ISBN 978-1-84376-513-4.

91. Graziani, A. The Theory of the Monetary Circuit. Thames Pap. Political Econ. 1989, 1, 1-26.

92. Minsky, H. Stabilizing an Unstable Economy, 1st ed.; McGraw-Hill Education: New York, NY, USA, 1986; ISBN 978-0-07-159299-4.

93. Lutz, F.A. Roads to Freedom: Essasy in Honour of Friedrich A. von Hayek; Streissler, E., Ed.; Augustus M. Kelley Publishers: New York, NY, USA, 1969.

94. Minsky, H. The Financial Instability Hypothesis: An Interpretation of Keynes and an Alternative to Standard Theory. Challenge 1977, 20, 20-27. [CrossRef]

95. Mellor, M. Could the money system be the basis of a sufficiency economy? Real-world Econ. Rev. 2010, 54, 79-88.

96. Piketty, T. Capital in the Twenty First Century; Belknap Press: Cambridge, MA, USA, 2014; ISBN 978-0-674-43000-6.

97. Binswanger, M. Is there a growth imperative in capitalist economies? a circular flow perspective. J. Post Keynes. Econ. 2009, 31, 707-727. [CrossRef] 
98. Douthwaite, R. The Ecology of Money; UIT Cambridge Ltd.: Bristol, UK, 1999; ISBN 978-1-870098-81-6.

99. Norgaard, R.B. Ecosystem services: From eye-opening metaphor to complexity blinder. Ecol. Econ. 2010, 69, 1219-1227. [CrossRef]

100. Gintis, H. Beyond Homo economicus: Evidence from experimental economics. Ecol. Econ. 2000, 35, 311-322. [CrossRef]

101. Kallis, G.; Norgaard, R.B. Coevolutionary ecological economics. Ecol. Econ. 2010, 69, 690-699. [CrossRef]

102. Røpke, I. FORUM: Prices are not worth much. Ecol. Econ. 1999, 29, 45-46. [CrossRef]

103. Farley, J. Conservation Through the Economics Lens. Environ. Manag. 2010, 45, 26-38. [CrossRef]

104. Rees, W.E. How should a parasite value its host? Ecol. Econ. 1998, 25, 49-52. [CrossRef]

105. Ayres, R.U. Eco-thermodynamics: Economics and the second law. Ecol. Econ. 1998, 26, 189-209. [CrossRef]

106. Spash, C. New foundations for ecological economics. Ecol. Econ. 2012, 77, 36. [CrossRef]

107. Daly, H. Steady-State Economics versus Growthmania: A Critique of the Orthodox Conceptions of Growth, Wants, Scarcity, and Efficiency. Policy Sci. 1974, 5, 149-167. [CrossRef]

108. Erickson, J.; Brown, P. Balance: Club of Rome Magazine, 2016; 8.

109. Nelson, J.A. Feminism, ecology and the philosophy of economics. Ecol. Econ. 1997, 20, 155-162. [CrossRef]

110. Brennan, T. Economy for the Earth: The labour theory of value without the subject/object distinction. Ecol. Econ. 1997, 20, 175-185. [CrossRef]

111. Mcmahon, M. From the ground up: Ecofeminism and ecological economics. Ecol. Econ. 1997, 20, $163-173$. [CrossRef]

112. Perkins, E. Explorations: Feminist Ecological Economics; Kuiper, E., Perkins, E., Eds.; Feminist Economics, 2005; Vol. 11, ISSN 1354-5701.

113. Brown, P.; Garver, G.; Helmuth, K.; Howell, R. Right Relationship: Building a Whole Earth Economy, 1st ed.; Berrett-Koehler Publishers: San Francisco, CA, USA, 2009; ISBN 978-1-57675-762-8.

114. Farley, J.; Burke, M.; Flomenhoft, G.; Kelly, B.; Murray, D.; Posner, S.; Putnam, M.; Scanlan, A.; Witham, A. Monetary and Fiscal Policies for a Finite Planet. Sustainability 2013, 5, 2802-2826. [CrossRef]

115. Douai, A. Value Theory in Ecological Economics: The Contribution of a Political Economy of Wealth. Environ. Values 2009, 18, 257-284. [CrossRef]

116. Farley, J.; Daly, H. Ecological Economics, 2nd ed.; Island Press: Washington, DC, USA, 2011.

117. Lawn, P. Facilitating the transition to a steady-state economy: Some macroeconomic fundamentals. Ecol. Econ. 2010, 69, 931-936. [CrossRef]

118. Roma, A. Energy, money, and pollution. Ecol. Econ. 2006, 56, 534-545. [CrossRef]

119. Singh, N.M. Payments for ecosystem services and the gift paradigm: Sharing the burden and joy of environmental care. Ecol. Econ. 2015, 117, 53-61. [CrossRef]

120. Daly, H. Nationalize Money, Not Banks. Center for the Advancement of the Steady State Economy, USA. 2013. Available online: https:/ / steadystate.org/nationalize-money-not-banks/ (accessed on 5 February 2019).

121. Keynes, J.M. Treatise on Money: V 1: The Pure Theory of Money; New Ed edition; Palgrave Macmillan: London, UK, 1930; ISBN 978-0-333-10724-9.

122. Dittmer, K. 100 percent reserve banking: A critical review of green perspectives. Ecol. Econ. 2015, 109, 9-16. [CrossRef]

123. Galbraith, J.K. Money: Whence It Came, Where It Went; Houghton Mifflin: Boston, MA, USA, 1975; ISBN 978-0-7351-0070-1.

124. Rezai, A.; Stagl, S. Ecological macroeconomics: Introduction and review. Ecol. Econ. 2016, 121, $181-185$. [CrossRef]

125. Jackson, T.; Victor, P.A. Does credit create a 'growth imperative'? A quasi-stationary economy with interest-bearing debt. Ecol. Econ. 2015, 120, 32-48. [CrossRef]

126. Miller, E. A Treatise on the Ecological Economics of Money. 2004. Available online: http:/ /www.h4x.ca/ TEEM/TreatiseEcologicalEconomicsMoneyEricMiller.pdf (accessed on 5 February 2019).

127. Fontana, G.; Sawyer, M. Towards post-Keynesian ecological macroeconomics. Ecol. Econ. 2016, 121, $186-195$. [CrossRef]

128. Cahen-Fourot, L.; Lavoie, M. Ecological monetary economics: A post-Keynesian critique. Ecol. Econ. 2016, 126, 163-168. [CrossRef]

129. Wray, L.R.; Innes, A.M. Credit and State Theories of Money: The Contributions of A. Mitchell Innes; Edward Elgar Pub: Cheltenham, UK; Northampton, MA, USA, 2004; ISBN 978-1-84376-513-4. 
130. Odum, H.T. Energy, ecology, and economics. Ambio 1973, 2, 220-227.

131. Gowdy, J.; Krall, L. The ultrasocial origin of the Anthropocene. Ecol. Econ. 2013, 95, 137-147. [CrossRef]

132. Gendron, C. Beyond environmental and ecological economics: Proposal for an economic sociology of the environment. Ecol. Econ. 2014, 105, 240-253. [CrossRef]

133. Spash, C.L. The shallow or the deep ecological economics movement? Ecol. Econ. 2013, 93, 351-362. [CrossRef]

134. Mellor, M. Ecofeminist Political Economy: Integrating Feminist Economics and Ecological Economics. Fem. Econ. 2005, 11, 107-150.

135. Mellor, M. The politics of money and credit as a route to ecological sustainability and economic democracy. Capital Nat. Soc. 2005, 16, 45-60. [CrossRef]

136. Dittmer, K. Communal Currencies. Lat. Am. Perspect. 2017, 44, 94-110. [CrossRef]

137. Dittmer, K. Local currencies for purposive degrowth? A quality check of some proposals for changing money-as-usual. J. Clean. Prod. 2013, 54, 3. [CrossRef]

138. Chick, V. Dow On Money, Method and Keynes: Selected Essays; Palgrave Macmillan: New York, NY, USA, 1992; ISBN 978-0-312-06815-8.

139. Mellor, M. Ecofeminist Political Economy and the Politics of Money. In Eco-Sufficiency and Global Justice: Women Write Political Ecology; Salleh, A., Ed.; Pluto Press: London, UK; New York, NY, USA, 2009; ISBN 978-0-7453-2863-8.

140. Dyson, B.; Hodgson, G. Accounting for Sovereign Money: Why State-Issued Money Is Not "Debt"; Positive Money: London, UK, 2016.

(C) 2019 by the author. Licensee MDPI, Basel, Switzerland. This article is an open access article distributed under the terms and conditions of the Creative Commons Attribution (CC BY) license (http:/ / creativecommons.org/licenses/by/4.0/). 